\title{
NECROMEMÓRIA: REFLEXÕES SOBRE UM CONCEITO
} NECROMEMORY: REFLECTIONS ON A CONCEPT

\section{Vandelir Camilo*}

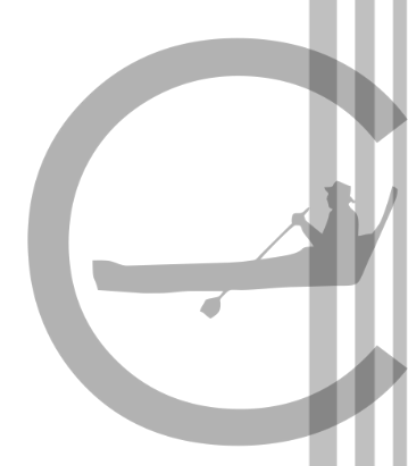

\section{Resumo:}

Este artigo aborda questões relativas a direitos e silenciamentos sociais relativos à memória colonial com ênfase na diáspora negra brasileira. Nesse sentido, norteia-se pelas noções de necropolítica e genocídio para explorar suas relações com o apagamento de fatos relativos a cultura afro-brasileira seja no apagamento de heróis, lugares, intelectuais e resistência negra no pensamento social em detrimento a uma concepção exclusiva do negro como submisso e incapaz de organização. A estes apagamentos, aspiramos, refletir a partir da ideia do conceito necromemória.

Palavras-chave: Necromemória; Necropolitica; Memória Social.

\begin{abstract}
:
This article addresses human issues and social silences related to colonial memory with emphasis on the Brazilian black diaspora. In this sense, it is guided by the notions of necropolitics and genocide to explore its relations with the erasure of facts related to AfroBrazilian culture, either in the erasure of heroes, places, intellectuals and black resistance in social thought to the detriment of an exclusive conception of black people. as submissive and incapable of organization. To these deletions we aspire to reflect from the idea of the necromemory concept.
\end{abstract}

Keywords: Necromemory; Necropolitic; Social Memory.

\footnotetext{
* Músico, mestre em história política (Escola Ciências Sociais, CPDOC FGV), doutorando em Memória Social, PPGMS, UNIRIO. Email:vrneves@yahoo.com.br
} 
"Como você faz um escravo? Você faz um escravo criando uma perda de memória; se você trabalhar uma perda de memória, você cria um estado de amnésia, então torna-se possível para os indivíduos não mais lembrar, e, quando eles não se lembram que estavam ligados às suas tradições, então eles seguem qualquer tradição..."

(Molefi Kete Asante, 1996)

\section{INTRODUÇÃO}

Este artigo aborda questões relativas a direitos humanos e silenciamentos sociais relativos à memória colonial da diáspora negra brasileira. Nesse sentido, norteia-se pelas noções de necropolítica ${ }^{1}$ e genocídio ${ }^{2}$ para explorar suas relações com o apagamento de memórias, fatos e sujeitos negros no pensamento social. Esta análise suscita questões pertinentes, controversas, históricas, filosóficas e cognitivas que eu gostaria de abordar ao longo deste texto.

É perceptível que, nos últimos anos, a memória tem sido um importante campo de investigações e pesquisas das ciências sociais, assim como tem sido uma área de interesses e demandas pela qual os sujeitos buscam, por meios de negociações e embates, apropriar-se dos fatos passados. De Henri Bergson a Proust; de Maurice Halbwachs a Durkheim, passando por Paul Ricœur e Pierre Nora, diferentes pensadores debruçam-se sobre a transdisciplinaridade da memória social. Em geral, essas discussões recaem em pensar a memória como um marco divisor entre o esquecimento e a lembrança. Em que pese às especificidades, o esquecimento é considerado exclusivamente como algo negativo; uma perda que deve ser evitada; um vazio cuja ausência de propostas tornar-seia uma espécie de limbo nos estudos sociais.

Uma das possibilidades muito pouco abordadas nesses estudos é a que diz respeito ao esquecimento como um campo social passível de análises, sobretudo em relação às representações e simbolismos que o constituem: apagamentos nos trabalhos de interação com o passado. O esquecimento pode ser induzido de formas diversas. Seu objetivo é, muitas vezes, estabelecer uma perda de ideias; uma perda de afetos que nos leva a questionar como ele nos afeta socialmente ${ }^{3}$.

\footnotetext{
${ }^{1}$ MBEMBE, Achillè. Crítica da razão negra. Editora n. 1 edições, 2018.

${ }^{2}$ Ver: LEMKIN, Raphael. Axis Rule in Occupied Europe: Laws of Occupation - Analysis of Government

- Proposals for Redress, Washington, D.C.: Carnegie Endowment for International Peace p. 79 - 95.1944 Disponível em: http://www.preventgenocide.org/lemkin/AxisRule1944-1.htm. Acesso em 16 de agosto de 2019. Ver também: NASCIMENTO. Abdias. O genocídio do negro brasileiro, 2016. São Paulo. Ed. Perspectiva.

${ }^{3}$ ROSSI, Paolo. Lembrar e esquecer. In: O passado, a memória, o esquecimento. São Paulo: EdUNESP, p. 15, 2010.
} 
O que proponho neste artigo é uma conceituação que busque responder a uma contingência de problemas que se constituem em relação aos silêncios e apagamentos de uma memória social. Neste caso do negro em diferentes momentos. O objetivo é mais analisar as condições de tais silenciamentos históricos relacionados a grupos vulneráveis - no caso, o sujeito negro - com base em diversos campos do saber como necromemória. Trata-se de uma tentativa emergencial de ventilar os problemas que são suscitados a partir da memória traumática, da desconsideração aos direitos humanos e dos apagamentos gerados, buscando, a partir de novas epistemologias, responder a esses embates.

Fundamental é, antes de tudo, definir em que sentido estou utilizando o conceito necromemória, já que o termo "necrose" remete às ciências biológicas e às questões que envolvem a morte de tecidos corpóreos ou de parte deles. Esta utilização está para além da dimensão patológica e desordenada da necrose: refiro-me, aqui, à morte ou esquecimento social por meio da qual determinada memória coletiva (grupal) é tornada necrosada, amortecida e, por conseguinte, torna-se fundadora de um projeto social, político, histórico, idealizado por setores de uma elite que busca abstrair partes de um processo de resistências de algum grupo da história. Por esse caminho, proponho, a necromemória, de natureza memorial, mantida em diversos campos que remetem ora a um apagamento, ora a uma fetichização de sujeitos negros exclusivamente como escravizados, objetificados e sexualizados no contexto nacional brasileiro, de modo que essa imagem é a que passa a ser objeto inserido na preservação do imaginário social. Além disso, questiono-me também sobre as necromemórias relativas aos corpos negros na trajetória do pensamento social brasileiro, na historiografia, na memória cultural e, finalmente, na normalização da violência e das mortes sofridas.

É preciso registrar que a produção de necromemória está submetida a diversas condições sociais, históricas, subjetivas e acadêmicas. É correto afirmar, por exemplo, que o Estado brasileiro provoca uma série de ações que a produzem, seja nos assassinatos de negros, nos crimes de feminicídio ou ainda nas manipulações cognitivas do indivíduo por meio de interações com o passado ${ }^{4}$. Outro exemplo está nas ações de sujeitos e instituições que expressam um pacto com o esquecimento, com o apagamento de

\footnotetext{
${ }^{4} \mathrm{O}$ departamento de Pós-Graduação em História da UNICAMP já vem, há alguns anos, pesquisando as representações do negro nos livros didáticos desde o período pós abolição até a atualidade. Não há, ainda hoje, a incorporação de contribuições da historiografia mais recente que busca evidenciar as estratégias de sobrevivência de sujeitos negros. Prevalece uma concepção do negro como submisso e incapaz de organização, o que reforça em estudantes do primeiro e segundo ciclo uma concepção negativa do sujeito negro. Ver: Garrido, 2017.
} 
determinadas memórias vergonhosas. Há elementos, portanto, que são determinantes na produção e institucionalização de necromemórias, e alguns deles estabelecem o lugar ocupado por uma história dita “oficial”, que consegue mobilizar estratégias políticas de apagamento coletivo, as quais passam por formas simbólicas e subjetivas, até que ocorra um silenciamento completo de um passado negro a partir da esfera pública 5 .

Meu interesse é iluminar as sucessivas atualizações do silenciamento no campo da memória social. Esquecimento e apagamento não se igualam, são projetos políticos que visam a integrar no presente as posições múltiplas de sujeitos que podem ser manipulados por meio das interações com seu passado. Na verdade, não está em jogo somente apagamento/silenciamento/esquecimento, mas, muito além disso, busco compreender as formas pelas quais tais memórias tornam-se necrosadas; por quais grupos tais necroses são evocadas, além de quais experiencias afetivas tais esquecimentos causam entre grupos diversos.

Para problematizar um pouco mais sobre o conceito de necromemória, parece-me fundamental apoiar-me em alguns atributos teóricos que me possibilitem trabalhar os aspectos dessas complexidades. Há uma rede de atores e instituições - como a religião, além de momento histórico, que formam uma teia complexa de racismos estruturais. A complexidade está nos acontecimentos, nas interações, nos acasos que regem nosso mundo fenomênico ${ }^{6}$. No mais, a leitura de Bruno Latour, em Jamais fomos modernos, onde o autor busca estabelecer uma práxis teórica que rompa com as barreiras disciplinares, foi inspiradora e instigou-me sobre as possiblidades no entorno desse conceito ${ }^{7}$.

De forma objetiva e construtivista, Latour desenvolve uma teoria sobre as mudanças sociais ocorridas a partir da modernidade no início do século XX que estabeleceram divisões entre diversos campos disciplinares. Deu-se um "nó górdio" que

\footnotetext{
${ }^{5}$ Um bom exemplo é referente ao Cais do Valongo e às questões que envolvem os simbolismos em torno desse lugar de memória, declarado Patrimônio da Humanidade pela UNESCO, é que caminhava para a perda do título em novembro de 2019. A prefeitura do Rio de Janeiro, então administrada pelo ex-pastor e ex-bispo da Igreja Universal do Reino de Deus, não realizou as contrapartidas impostas pela UNESCO, como a criação de um museu e conservação de todo o patrimônio. Será o primeiro título da Humanidade perdido pelo Brasil, coincidentemente relativo à diáspora negra. Em recente discurso, o vereador Reimont declarou que "A inação da Prefeitura do Rio poderá fazer o Brasil perder o título de Patrimônio da Humanidade, outorgado em julho de 2017, pela Unesco, ao Cais do Valongo, onde desembarcaram milhões de africanos sequestrados para servirem de escravos no Brasil. Se isso acontecer, atestará o desprezo desta gestão pela Cultura e pela História afro-brasileiras e será também uma humilhação internacional". Fonte: http://reimont.com.br/noticias/cais-do-valongo-sob-ameaca/. Acesso em: 4 ago. 2019.

${ }^{6}$ MORIN, Edgard. Introdução ao pensamento complexo. Porto Alegre. Ed. Sulina, 2005

${ }^{7}$ LATOUR, Bruno. Jamais fomos modernos: ensaio de antropologia simétrica. Tradução de carlos Irineu da Costa. 2. Ed. Rio de janeiro: Ed. 34, 2009
} 
provocou profundas barreiras entre as disciplinas. Essas divisões, as barreiras disciplinares, muitas vezes atrasam quaisquer possibilidades de diálogo e conhecimento transdisciplinar e são o que provoca uma formação intelectual deficitária e irreal ao privilegiar o estudo de partes em detrimento do todo.

Por esse viés transdisciplinar, parece-me fundamental propor diferentes possibilidades para o conceito de necromemória. De fato, o termo ilumina apagamentos e silenciamentos de memória sem igualá-los no conteúdo, na medida em que são ações que objetivam manipular, no presente, diferentes interações de recortes do passado, a fim de realizar uma projeção para o porvir. Assim sendo, debruço-me, em especial, sobre a memória colonial brasileira, em virtude de todo processo que, ainda hoje, mantém as mesmas práticas de violência e covardia por meio de uma autoridade despótica ${ }^{8}$.

\section{NECROMEMÓRIA}

Neste artigo, proponho que a conceituação de necromemória é a expressão do poder e a capacidade de determinado Estado (necropolitica e necropoder) manipular as construções, as representações e os destinos políticos de determinado grupo, a partir das interações do passado com o qual esse grupo terá acesso, mantendo constante a mortificação de determinadas memórias.

O que me chama atenção nesse processo de manipulação de memórias é a vulnerabilidade dos corpos negros. A memória que mais se apaga são dos corpos vulneráveis. O sangue que mais se derrama é dos vulneráveis indígenas, pobres e negros. A memória do sujeito negro é apagada simbolicamente ou por meio de uma violenta política aplicada a partir de um Estado religiosamente fundamentalista. Além disso, da grande mídia à historiografia nacional, da memória ao pensamento social brasileiro relacionado ao passado/presente desses corpos negros, há um viés que se constitui, antes de tudo, em uma estética do silenciamento, manipulado por parte de diferentes setores elitistas brasileiros.

Necromemória é uma política pública de Estado. Ela visa a decidir como e a partir de quais enquadramentos a memória negra brasileira será atualizada. Um enquadramento de memória é, por si só, um ato de violência que pode ocorrer através da historiografia nacional, dos processos patrimoniais ou por meio de representações e usos sobre o passado por meio de uma indústria cultural. Há uma política (presente) em determinar o

\footnotetext{
${ }^{8}$ MBEMBE, Achillè. Crítica da razão negra. Editora n. 1 edições, 2018.
} 
enquadramento do que lembrar (passado) para projetar o lugar do negro no porvir (futuro), para isso destruindo traços de identificação cultural, linguística e religiosa.

A necromemória é um projeto da elite econômica, política, social e acadêmica brasileira ${ }^{9}$. Para compreender tal afirmação é preciso notar que a manipulação da memória social do negro neste país constitui os interesses dessas elites que buscam ora silenciar, ora apagar as possibilidades de interação com o passado. A justificativa de tal perversidade é baseada na manutenção corolária do mito da democracia racial, que justifica a igualdade das raças, dos direitos à memória, pregando a cordialidade e a união dos povos como característica típica da "identidade" brasileira.

Ainda que não seja o interesse deste ensaio questionar e criticar as questões que envolvem os usos sobre o mito democrático racial neste país e seus reflexos na memória social, penso ser primordial demonstrar a força que esse mito representa, ainda hoje, no imaginário social brasileiro. Para isso, convido a professora Jô Gondar (2011) e o pensador Jean-Pierre Vernant (1973) ao debate no que concerne a dialogar sobre diferentes processos na construção processual da memória. Vernant (1973), ao problematizar o Mito e pensamento entre os gregos, a partir dos processos de criação que envolvem a magia e a narrativa da mitologia grega, re-passada de geração a geração, é indicativo sobre a possibilidade de se analisar essas representações como uma construção de memória, ainda que caracterizada por outras formas de discurso, representação e simbolismos. Para o autor, o mito nunca desaparece; ele vive em contradição, mas é eterno. O mito torna-se avulso aos livros, aos seus lugares de memória, ele passa a se perpetuar assumindo, a partir de diferentes pessoas e narrativas, a eternidade.

Para Jô Gondar ${ }^{10}$, por sua vez, esse processo de criação e manutenção do mito não é, ainda, uma memória social, ou seja, é uma memória ontológica que possibilita a revelação de um ser eterno e imutável. Por esse sentido, diacronicamente, penso ser a fundação do mito da democracia racial brasileira uma criação de memória "ontológica", muito bem planejada pela elite brasileira ${ }^{11}$ e que tem como objetivo, ainda hoje, a revelação, ou melhor, a manutenção de uma ausência de ideia de preconceito racial no

\footnotetext{
${ }^{9}$ SOUZA, Jessé. A elite do atraso: da escravidão a lava jato. Rio de Janeiro. Ed. Casa da Palavra, p.146, 2017.

${ }^{10}$ GONDAR. Jô. Cinco Proposições sobre Memória Social. Morpheus. No ${ }_{9}$, v. 15, p. 19-40, 2011.

${ }^{11}$ SOUZA, Jessé. A elite do atraso: da escravidão a lava jato. Rio de Janeiro. Ed. Casa da Palavra, p.73, 2017; SCHWARCZ, Lilia. O espetáculo das raças: cientistas, instituições e questão racial no Brasil, 18701930. São Paulo: Ed. Companhia das Letras, p.67, 1993.
} 
Brasil. O conceito desse mito é, justamente, constituir uma ideia imutável da união das raças - negra, indígena e branca - como formuladoras de um único povo brasileiro

Esse mito manifesta-se em diversas estruturas estatais, empresariais e sociais. Ser manipulador de memórias, a partir do mito da democracia racial, é exercer um controle sobre a definição do passado de determinado grupo vulnerável racialmente; é exercer o controle perverso sobre a ideia de que não somos um país racista; mais do que isso: é firmar uma falsa igualdade de raças e direitos igualitários entre negros e brancos que abafa quaisquer discussões relativas ao racismo, seja no campo da historiografia, do pensamento intelectual, da memória social ou, até mesmo, dos direitos humanos.

Assim sendo, é importante atentarmos para questões que envolvam direitos (humanos) e direito à memória. Quando o jurista polonês Raphael Lemkin criou o termo e conceituou o genocídio como o extermínio deliberado, parcial ou total de uma comunidade, grupo étnico, racial ou religioso por um viés ideológico, no pós-guerra, houve ali uma tentativa generalista em denunciar as peculiaridades do extermínio em virtude dos efeitos do holocausto e das guerras. Entretanto, não impediu, ou melhor, não impede que novos genocídios ocorram de acordo com novas práticas de matanças e sevícias adotadas contra outros grupos vulneráveis. Além do que, é preciso registrar que direitos e memória não foram particularizados em relação às causas e aos eventos colonialistas tanto na Africa como nas diásporas ${ }^{12}$.

Por esse ângulo, minha intenção transforma-se em apontar as dificuldades de generalizar os silenciamentos e os apagamentos de memórias negras brasileiras univocamente como genocídio memorial. Apesar de intelectuais e pensadores como Abdias Nascimento ${ }^{13}$, Lelia Gonzalez ${ }^{14}$, entre outros, apropriarem-se do conceito de genocídio para denunciar crimes cometidos contra a população negra, não há ferramentas jurídicas ou revisionistas que busquem, por exemplo, condenar questões relativas à escravidão ou ao alarmante índice de assassinatos de sujeitos negros e negras neste país por genocídio ${ }^{15}$. Ainda que possa afirmar que a população afro-brasileira conviva

12 Fonte: http://agenciabrasil.ebc.com.br/direitos-humanos/noticia/2017-12/negros-brasileiros-nao-tempor-que-comemorar-declaracao-dos-direitos. Acesso em: 10 ago. 2019.

${ }^{13}$ NASCIMENTO. Abdias. O genocídio do negro brasileiro, 2016. São Paulo. Ed. Perspectiva.

${ }^{14}$ GONZALEZ, Lélia. Por um feminismo Afro-latino-Americano. In Caderno de Formação do Círculo Palmarino. n. 1. Batalha de ideias. São Paulo. Ed AfroLatinoAmerica, 2011.

${ }^{15} \mathrm{O}$ crime de genocídio foi tipificado no Brasil em 1 de outubro de 1956 . O único brasileiro condenado por crime de genocídio foi o garimpeiro Pedro Emiliano Garcia, por coordenar um massacre na tribo de Haximu, em 1993, executando mulheres, crianças e velhos. Fonte: https://www1.folha.uol.com.br/poder/2018/11/policia-federal-prende-em-roraima-garimpeiro-condenadopor-genocidio.shtml. Acesso em: 4 ago. 2019. 
diariamente com práticas de genocídio, penso que há necessidade de analisar o debate sobre essas questões de silêncios e apagamentos da memória social colonial brasileira que se reflete ainda hoje a partir de um viés decolonial.

Mas, afinal, quais são as formas práticas de se exercer o genocídio no mundo contemporâneo? Quem são os sujeitos desse genocídio? O que a conceituação de genocídio, nos dias de hoje, pode dizer sobre as constantes políticas de apagamento e silenciamento de corpos e passados negros? A noção de genocídio é suficiente para contabilizar as formas contemporâneas de extermínio de negros e negras neste país? Se sim, por que não há meios de impedir tais barbáries no mundo contemporâneo?

Judith Butler ${ }^{16}$ e Achillè Mbembe ${ }^{17}$ podem referenciar-nos ao debaterem sobre a vulnerabilidade de determinados corpos mediante a força de um Estado que, sob a forma de soberania, possui autonomia para a destruição dos corpos e dos grupos eleitos como seus inimigos. Há uma política em vulnerabilizar determinados corpos a toda espécie de mazelas geradas pelo terror psicológico, pelo frio, fome e racismo. Há uma política estatal de eliminação de quaisquer espécies de corpos, memórias e patrimônios de quais quer grupos vulneráveis em nossas sociedades.

Fernando $\mathrm{Baez}^{18}$ conceitua a destruição do patrimônio material e imaterial na América Latina por invasores europeus como memoricídio. Esse conceito busca denominar toda a destruição de patrimônios culturais de quaisquer grupos vulneráveis socialmente, sejam os nativos ou os negros. Compreendo que essa destruição, relativa ao patrimônio do povo negro brasileiro, dar-se-á em formas múltiplas e complexas, em um caráter mutável e perverso, no apagamento destrutivo de determinados passados entendidos como de re-existências - o que dificulta quaisquer espécies de interações de memórias na contemporaneidade. Por outro lado, essa destruição pode dar-se, também, por meio de uma espécie de esquecimento manipulável e muito bem projetado, visando a atender a interesses diversos. Entendo que memoricídio atualmente não privilegia todas as peculiaridades na destruição, no silenciamento e no apagamento da memória cultural afro-brasileiro $^{19}$.

\footnotetext{
16 BUTLER. Judith. Introdução. In Quadros de guerra. Rio de Janeiro: Civilização Brasileira, 2015, pp. 13-55.

${ }^{17}$ MBEMBE, Achillè. Crítica da razão negra. Editora n. 1 edições, 2018.

${ }^{18}$ BAEZ, Fernando. A história da destruição cultural da América Latina: da conquista à globalização. Rio de Janeiro: Editora Nova Fronteira, 2010.

${ }^{19}$ Outro conceito em apologia ao genocídio foi criado pelo cientista político Rudolph Joseph Rummel 1994, como democídio. O conceito busca incluir outras formas de assassinatos não cobertas pelo genocídio apontando todos os crimes cometidos por governos contra determinados grupos. O termo teve aceitação no meio acadêmico norte-americano. Contudo, é importante frisar que em seu livro, Death by government, de
} 
Paul Ricœur ${ }^{20}$ privilegia em seus estudos relativos ao esquecimento social como um vasto campo de investigação e problematização nas ciências sociais. Para esse pensador, o esquecimento pode ser operado tanto como uma memória impedida quanto como uma memória manipulada. Assim, Ricœur defende a tese de que a memória manipulada resulta de uma má fé, operada por agentes responsáveis pelas narrativas oficiais que buscam enquadrar as narrativas pretéritas de forma genealógica. Contudo, para o autor, essa manipulação memorial é a responsável por um "não querer saber": uma memória vergonhosa ou um evento traumático de determinado grupo.

Outra proposta para o esquecimento é defendida por Andreas Huyssen (2014), para quem esse fato social é, sim, um ato político. Entretanto, o autor sustenta que o esquecimento pode ser o produto de uma política que, em alguma instância, pode provocar-nos o querer saber, o que faria surgir efeitos contrários ao projeto de se esquecer as mesmas memórias vergonhosas ou traumáticas.

Considero construtivas as propostas de ambos os pensadores e busco seguir as pistas de Ricœur relativas ao fato de que nossa interação com a memória é extremamente manipulada. Contudo, o meu interesse é ir além da oposição querer saber/não querer saber, por isso proponho a ideia de uma memória clivada. Postulo que nossa memória em não querer saber é formulada de forma clivada, o que atende a interesses diversos que buscam representar o negro, por exemplo, a partir das iconografias do período colonial ou por meio de histórias ditas oficiais, exclusivamente como um homem-objeto-animal da sociedade, como diria Mbembe ${ }^{21}$. A clivagem é uma cisão, uma dissociação que, na psicologia, é um mecanismo de defesa bem-definido. É uma divisão ou polarização de crenças, ações, objetos e pessoas, entre boas ou más, concentrando-se em seus atributos, positivos ou negativos. A necromemória pode ser indicativa dessa memória clivada, localizada em diferentes setores de nossa sociedade e instituições, concentrando-se unicamente em exaltar aspectos depreciativos e negativos relacionados à população diáspora.

Dito isso, estarei interessado, neste ensaio, em analisar os apagamentos e os silenciamentos relativos a corpos negros entendendo-os como uma construção de

1994, Rummel trabalha com diferentes formas de governo que praticaram assassinatos, entretanto exclui o povo africano ou da diáspora negra de seus debates.

${ }^{20}$ RICOUER, Paul. A memória, a história, o esquecimento. Tradução: Alain François. Campinas: Editora da UNICAMP, 2007.

${ }^{21}$ MBEMBE, Achillè. Necropolitica. Biopoder, soberania, estado de exceção. Editora: n. 1 ediçoes. São Paulo, 2018 
memória, ausente de agência, de vozes ou direitos. Nossa memória é doente, é necrosada, é amórfica, é uma pústula que faísca em um corpo social. Esse corpo socialmente vivo é, justamente, onde se localizam nossas histórias oficiais por um lado que representam o negro unicamente como o e sujeito escravizado, sem voz, sem direito, sem projeção. Busca-se assim, apagar as histórias de liberdade, resistência, guerrilhas, revoltas e reinvenções de sujeitos negros e negras durante diversas épocas.

As nossas instituições são nossos órgãos vitais, estruturados de forma conjuntiva a exibir nossas feridas necrosadas de nós mesmos. Fomos somente escravizados, insistem em nos convencer. O negro não tem histórias ditas heroicas. Assim sendo, não queremos saber. Por esse não querer saber, por essas necroses sociais sobre os corpos vulneráveis é que a necromemória floresce e viceja seus frutos.

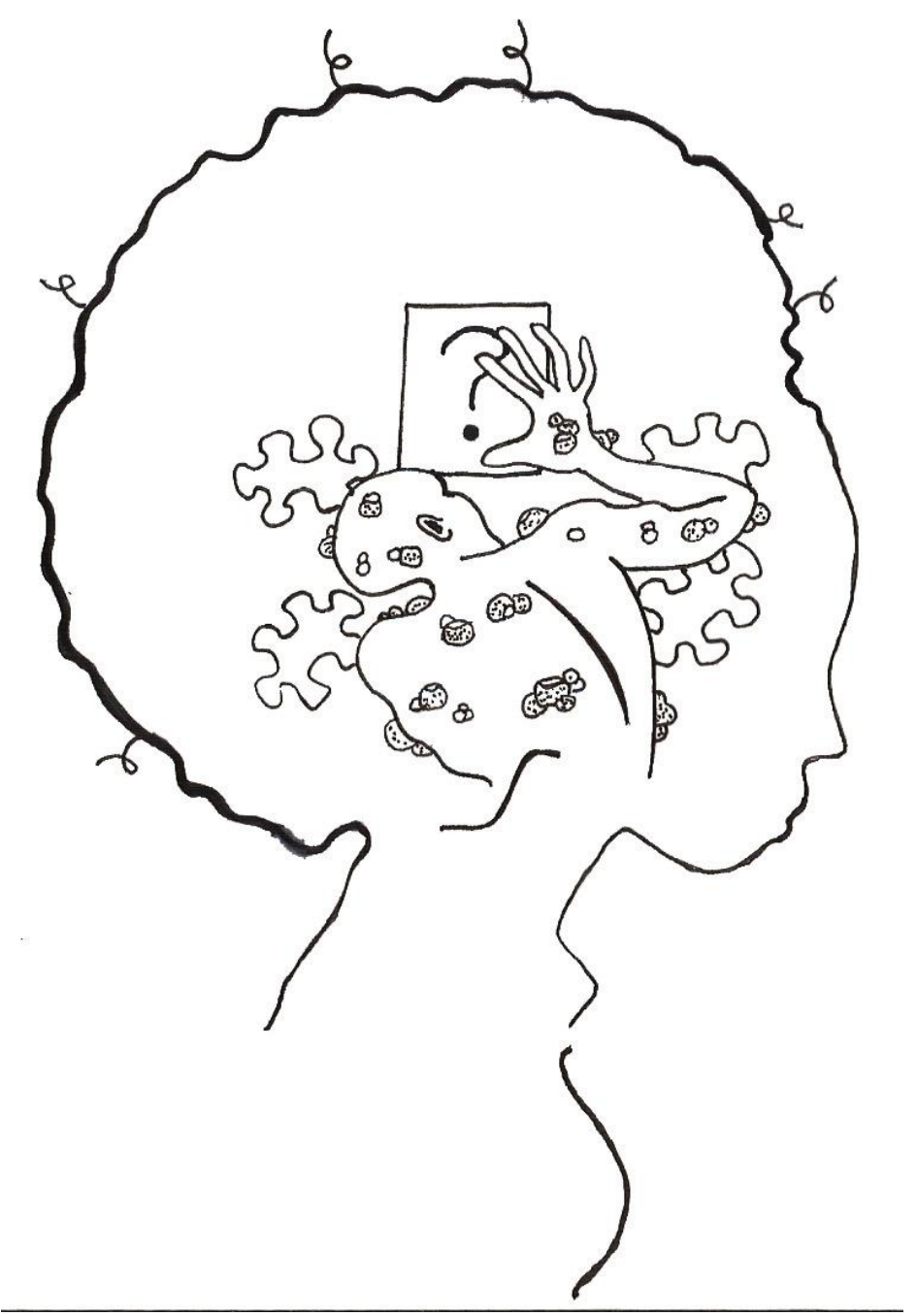

Figura 1.0 - "Necromemória". Desenho para este ensaio @ phillipe_knippel, Recife, 2019 


\section{A NECROMEMÓRIA NOS SILÊNCIOS}

O conceito de necromemória pode ser relativizado em distintos campos das ciências, das artes, da sociedade, das políticas públicas, da geopolítica, etc. A necromemória pode ser acionada em todo processo de interação com o passado colonial negro, na medida em que já pressupõe uma memória morta relativa as resistências de sujeitos negros em diferentes épocas e formas. Ela opera é nos silêncios manipulados e nos apagamentos forçados de histórias ditas extras-oficiais de sujeitos e fatos heroicos negros e tem como habitat natural o apagamento por histórias ditas oficiais. Se a historiografia "oficial" brasileira busca registrar e estabelecer uma narrativa oficial dos feitos e fatos passados, dos heróis, como fica representado o ser negro nesse debate?

Há, no caso brasileiro, um espectro de estratégias de apagamento: uma política de esquecimento público que coloca o negro nas representações como o farrapo humano; é o infra-humano e, no imaginário social brasileiro, "uma figura desgarrada, arruinada, irreconhecível, estragada, uma entidade que perdeu sua autenticidade"22. Sem autenticidade, esse sujeito perde sua agência que é, a capacidade do sujeito dispor de recursos psicológicos e culturais necessários para o avanço de sua liberdade humana o que, por sua vez, estratifica a ideia de identidade. Quem sou eu? De onde vim? Para onde vou? Essas questões, muitas vezes, fazem parte de um deprimente espetáculo de alienações eurocentristas em que a elite brasileira premia o negro como ator coadjuvante de sua autoalienação. Pois, assim, em estado alienado, despolitizado, torna-se o corpo negro um animal mais tolerado socialmente.

A ideia de identidade nacional formulada pelos antigos Estados-Nações propunha agenciar as vitórias de seu povo forjando seus heróis por meio de representações que justificassem um passado a partir de lugares de memória (monumentos, feriados, histórias). No caso brasileiro, esse período de construção identitária (na república) coincide com nossa pós-abolição da escravatura, quando as propostas privilegiavam a estética euro-cristã. Assim, apagou-se uma possibilidade em abordar um passado de resistências e vitórias de sujeitos negros, bem como seus fatos e lugares de referência como os construtores do Estado brasileiro, elegendo-se, portanto, unicamente heróis brancos e seus feitos.

Os estrangeirismos confortam-nos de um passado moldado na escravidão. Sobra, ao negro, a imagem do sujeito necrosado pelo sistema colonial. O corpo negro é a necrose

\footnotetext{
${ }^{22}$ MBEMBE, Achillè. Crítica da razão negra. Editora n. 1 edições, 2018.
} 
da sociedade; é o tecido social amortecido. Todo seu passado é de inanição e necessita ser escondido em vez de ser tratado, uma vez que toda sua ferida à mostra causa constrangimento e precisa ser tapada. As marcas do corpo humano têm histórias; as verdades não desaparecem com os tapumes sociais. A necromemória é, justamente, a nossa ferida. Ela é a chaga social que nos liga diretamente ao passado, mas cala-nos no presente.

Penso que, neste momento, faz-se necessário recorrer a esse conceito de forma transversal e polissêmica: nos estudos acadêmicos ou pesquisas culturais que privilegiem aspectos subjetivos dos silêncios e apagamentos do patrimônio, da historiografia e da memória colonial brasileira refletidos até a atualidade. A necromemória pode ser trabalhada a partir de disciplinas distintas, uma vez que não pertence ao bojo de qualquer área disciplinar específica. O historiador, o músico, o psicanalista, o linguista ou o militante pode apropriar-se desse conceito em sua atuação e, a partir de então, observar diferentes condições sobre seus usos. Além disso, compreendo a possibilidade de sua aplicação em análises sociais que remetam às práticas reiteradas de violência contra o povo negro, posto que é a violência colonial que não passa, cujos efeitos, ainda hoje, colocam o grupo que foi colonizado em uma posição insustentável.

Em um primeiro momento, reflito sobre a necessidade de se problematizar esse conceito no que concerne ao lugar ocupado por corpos negros na trajetória social deste país desde o processo colonial. A necromemória é uma forma de denúncia que visa a colidir com ideias normativas relacionadas, por exemplo, ao silenciamento e ao apagamento desses corpos, na medida em que busca jogar luz sobre as formas que mantemos, até o presente momento, os silêncios insustentáveis da violência sobre o colonizado, sobre as brutalidades e desprezos pelo corpo negro ${ }^{23}$.

Fora do continente africano, o Brasil é o país que possui a maior concentração populacional de origem negra no mundo. Atualmente, $55 \%$ da população desse país é formada por negros e pardos. Contudo, a matança dessas pessoas não é indicativo, por exemplo, de políticas públicas ou formas de condenação desse genocídio praticado contra os negros. Segundo dados da Organização das Nações Unidas (ONU), jovens negros são

\footnotetext{
${ }^{23}$ BIKO, Stephen. Escrevo o que eu quero. São Paulo: Ed. Ática, p.39, 1978; FANON, Franz. Peles negras; máscaras brancas. Salvador: EDUFBA, p.103, 2008; MBEMBE, Achillè. Crítica da razão negra. Editora n. 1 edições, p.28, 2018.
} 
assassinados diariamente a cada 23 minutos neste país: são 63 assassinatos por dia, com faixa etária entre 15 a 29 anos, resultando em 23.100 jovens negros assassinados ao ano ${ }^{24}$.

A taxa carcerária do país tem, nos negros, sua representação máxima, seja nos abrigos infanto-juvenis ou nos presídios. As comunidades ou favelas compostas, em grande parte, por negros e negras são vulneravelmente expostas a todos os tipos de violências físicas e psicológicas. Além disso, a violência é crescente contra as mulheres negras, segundo os últimos dados do Atlas da Violência ${ }^{25}$. Elas são mais expostas a todos os tipos de violências física e psicológica: às mais bárbaras atrocidades criminosas acompanhadas das sevícias domésticas, culminando no feminicídio (sexual, doméstico e reprodutivo). Os casos de assassinatos seguem em taxa crescente em uma média de treze homicídios por dia. É no silêncio desse sangue que escorre diante dos nossos olhos diariamente; é no mais absoluto e conformado silêncio da nossa existência que a necromemória entra em seu estado mais pulsional genocida, como diria Franz Fanon.

Os racismos institucionais têm, na necromemória, a sacralização de sua conceituação. Judith Butler ${ }^{26}$ problematiza o fato de determinados corpos serem literalmente escolhidos como os vulneráveis. Esses ficam expostos a todas as espécies de barbárie, maus tratos, desatenção por parte do Estado e, finalmente, à morte. É primordial ter em mente que essa vulnerabilidade somente ocorre em um processo sociologicamente construído. Há uma construção ideológica e segregacionista para determinar quais corpos terão direito à vida, a um passado e a uma memória.

O nosso silêncio histórico diante dessas mortes negras é desconcertante e constrangedor; é um não querer saber que nos anestesia e absolve-nos de nossas culpas diárias. Não falamos de racismo para não falar de nossas necroses sociais. Poderia a necromemória ter uma função social ao jogar luz a questões não ventiladas; poderia servir de farol em nossas vergonhosas memórias capitais. A proposta é essa, a partir das práticas cognitivas coloniais, referenciar-nos em uma teoria descolonial que possa dar voz às cores da memória colonial brasileira ${ }^{27}$.

\footnotetext{
${ }^{24}$ Fonte: https://nacoesunidas.org/onu-mulheres-chama-de-escandalo-morte-de-23-mil-jovens-negros-porano-no-brasil/. Acesso em: 5 ago. 2019.

${ }^{25}$ Fonte: https://www.bbc.com/portuguese/brasil-48521901. Acesso em: 5 ago. 2019.

${ }^{26}$ BUTLER. Judith. Introdução. In __ Quadros de guerra. Rio de Janeiro: Civilização Brasileira, 2015, pp. 13-55

${ }^{27}$ Em 2015, em uma pesquisa produzida pela Faculdade Latino America de Ciencias Sociais com o apoio da ONU, constataram-se as cores da violência no país. Em 2015, registrou-se queda de 11,9\% na taxa de homicídios de mulheres brancas; no mesmo ano, a taxa de homicídios de mulheres negras cresceu 19,5\%. Fonte: encurtador.com.br/hjCM0. Acesso em: 16 de agosto de 2019
} 
A normalização no assassinato de homens e mulheres negras é uma questão visível e regularizada desde o período escravocrata até a atualidade. Nesse ponto, certamente é onde a nossa memória mais necrosou-se. É ferida que provoca um veneno, insistiria Fanon ${ }^{28}$. As mortes silenciadas clamam de nós uma postura diante dessas necroses memoriais, herança direta de um passado colonial. A necromemória necessita urgentemente de ser debatida, problematizadas confrontadas diante de tantas mortes é o que brada a professora e historiadora Beatriz Nascimento após os cinco tiros que a tiraram de nosso convívio.

Como venho defendendo, há uma política estatal e social de silenciamentos e apagamentos de memórias sociais-coloniais-negras por parte da elite brasileira. O projeto é perverso. A elite reivindica e estabelece o monopólio da inteligência e do julgamento moral. Para isso, assenta limitações às interações com o passado e às aspirações do que os negros poderão reconstruir do passado. A arrogância intelectual da branquitude normaliza uma situação sine qua non onde brancos tem um mandato divino para imporem seu ritmo e seus valores aos negros ${ }^{29}$.

Torno a dizer que a necromemória pode ser abordada em futuros trabalhos em seus aspectos relacionais com a historiografia e a memória social brasileira relativa a fatos relacionados a reconstrução do passado colonial brasileiro. Interesso-me particularmente por entender como, na historiografia abordada nas escolas de nível básico e fundamental, o ser negro é reconstituído, como esse ser é trabalhado no imaginário social de crianças e adolescentes em importante fase de desenvolvimento cognitivo. ${ }^{30}$ Mais ainda, interessome, a partir da iconografia do período colonial, por propor um debate visual sobre o lugar ocupado por corpos negros. Além disso, o campo da memória social pode ser profícuo para analisar as interações contemporâneas relativas ao processo da memória colonial brasileira e sua relação no estabelecimento das narrativas oficiais.

Acho necessário relativizar que, no campo da historiografia brasileira, os recentes debates já questionam a visão unívoca que prevalece em olhar o sujeito negro no período

\footnotetext{
${ }^{28}$ FANON, Franz. Peles negras; máscaras brancas. Salvador: EDUFBA, 2008.

${ }^{29}$ BIKO, Stephen. Escrevo o que eu quero. São Paulo: Ed. Ática, p.79, 1978.

${ }^{30}$ Em setembro de 2021 o Grupo Cia das Letras se viu obrigado a se desculpar publicamente em virtude da publicação do livro abc da liberdade: a historia de Luiz Gama, o menino que quebrou correntes sem palavras. A obra de José Roberto Torero e Marcus Pimenta era uma publicação infanto-juvenil que relativizava a escravidão a partir de brincadeiras infantis. Após sucessivas críticas, a editora retirou o livro de circulação alegando não ter passado por revisão. Todavia, desde 2015, data do primeiro lançamento o livro já circulava em todo o território nacional. Fonte: Companhia das Letras recolhe livro com crianças em navio negreiro (uol.com.br). Acesso em 9 de dezembro de 2021
} 
colonial unicamente ou exclusivamente como o ser escravizado (sem agência) na história da sociedade brasileira. O pensador Walter Benjamin ${ }^{31}$ realizou pertinente crítica sobre os perigos da historiografia em Sobre o conceito de história na reconstrução do passado e em sua transmissão que se dá, muitas vezes, de forma coercitiva e sustentada pelas classes dominantes.

Nesse sentido cabe uma interrogação relacionada a esse passado colonial: por que Mefisto nosso país recorre, interessadamente e manipulavelmente, a esse passado colonial representando o negro única e exclusivamente como um sujeito escravizado, o homemobjeto, homem-mercadoria e o homem-moeda $?^{32}$

\section{MEMÓRIA COLONIAL E POLÍTICA}

A colonização europeia foi a maior responsável pela exploração, invasão, esfoliação, estupro e dilaceração cultural da África e de suas diásporas ao longo dos últimos séculos.

Abdias Nascimento ${ }^{33}$ lembra-nos que foi um empreendimento sofisticado e muito bem-planejado, com as bênçãos do cristianismo, que foi responsável por criar o projeto de assimilação cultural defendido com diversos nomes: "evangelismo", "conversão dos pagãos", "aceitação de Cristo"; dentre outras práticas que objetivaram criar todo um ambiente de alienação e manipulação religiosa fundamentalista de origem euro-judaicocristã - a qual busca, até hoje, colonizar e converter religiões não cristãs.

Franz Fanon ${ }^{34}$ afirma que esse violento processo colocou tanto colonizados como colonizadores em um estado de psicotização. Essa alienação colonial é a impossibilidade de nos constituirmos enquanto sujeitos de nossa história. Por mais que saibamos quem é o inimigo, segundo Fanon, há uma alienação constante em sujeitos negros e brancos de ordem objetiva e subjetiva. Nesse sentido, essa subseção é necessária na medida em que essa alienação é alicerce de nossas memórias coloniais, o que nos leva apontar e questionar o que e como isso afeta-nos no presente.

Dito isto, como poderíamos compreender a memória colonial, em analogia às proposições do campo da memória social? O que me interessa neste ensaio é, a partir desta, articular propostas para aquela, embora o objetivo não seja apresentar as diferenças

\footnotetext{
31 BENJAMIN, Walter. Sobre o conceito de história. . In: Arte e politica. Rio de Janeiro: Brasiliense, p. 222-232, 1985.

32 Ver: Mbembe-

${ }^{33}$ NASCIMENTO. Abdias. O genocídio do negro brasileiro, 2016. São Paulo. Ed. Perspectiva.

${ }^{34}$ FANON, Franz. Peles negras; máscaras brancas. Salvador: EDUFBA, 2008. . Obras Escolhidas. Magia e técnica,
} 
representacionais entre "social" e "colonial", mas sim apontar as similaridades argumentativas. É preciso registrar, antes de tudo, que a memória colonial está ligada a uma violência empírica que pressupõe uma restrição social e cultural, moldada no racismo, ilustrada no desprezo e cativada na agressividade e nos rituais de humilhação.

O trabalho de reconstrução da memória colonial é dado em um espaço de disputas, batalhas e negociações em que diferentes grupos buscam organizar seu passado. São modos de seleção e olvidos: de o que lembrar, mas, principalmente, como se lembrar. Contudo, na reconstrução da memória colonial, não há um processo de negociações dos grupos envolvidos; os processos não ocorrem de forma harmônica, mas por meio de duelos e interesses muito bem-estabelecidos.

As disputas, no presente momento, dão-se entre os herdeiros sociais dos mesmos grupos históricos que divergiam no passado. De um lado, os grupos vulneráveis ou vitimizados pelo sistema colonial - negros e índios que trazem nos corpos as marcas da colonização. Esses detentos de suas próprias raças são os resultados do trabalho brutal, formalizado a partir do controle de seleção de suas próprias memórias. As antigas violências múltiplas impõem-se, ainda hoje, seja por meio da força física, do sangue ou do encurralamento cultural.

Do outro lado, os colonialistas ou seus herdeiros de memória que têm como função atualizar o projeto do colono. É necessário requalificar a violência para justificar a morte, por isso buscam impor um projeto de rememorar o passado de acordo com suas obstinações, as quais estão moldadas historicamente na intimidação, na desumanização e na sujeição dos diferentes. Nas condições contemporâneas, há uma política de memória racialmente institucionalizada em nossa sociedade, além dos racismos recreativos que só se explicam pela desumanização das memórias sociais e dos corpos negros em razão dos nossos passados coloniais.

O processo de interação com a memória colonial que concerne ao passado de sujeitos negros configura-se em um projeto que busca, muitas vezes, silenciar a produção de seus saberes e resistências, posto que os representa exclusivamente como herdeiros dos escravizados. Os homens-objetos, seres arredios e herdeiros diretos do mal da humanidade. O sujeito negro torna-se, a partir das interações contemporâneas, uma silhueta de calcinados e o envenenamento simbólico que, desde a época colonial, nos 
propõe a um vazio de misérias que nos representam predispostos ao vício, à mentira, à erotização e à incapacidade intelectual ${ }^{35}$.

Para isso, recorre-se a políticas explicitas de apagamento, silenciamento e manipulações simbólicas nas interações com o passado. Não há ética nesses processos políticos de reconstrução da memória colonial; o que se almeja é retirar a agência de sujeitos negros ou fatos considerados heroicos pelos herdeiros de uma memória cultural afro-brasileira. Há uma escolha política em sujeitar o negro à imagem de ser animalizado semi domesticado. A semi domesticação pode, muitas vezes, elevar o negro ao patamar da estima em relação a branquitude, assim como os animais domésticos tornam-se estimados por seus donos.

Além disso, não é dada voz a pensadores negros para expressarem suas epistemologias no tocante a memórias traumáticas do período colonial e seus efeitos na memória grupal nos dias de hoje. Busca-se manter uma subjugação entre memórias, mostrando a clara obstinação em alienar as particularidades e as subjetividades no processo da memória traumática do sujeito negro, conduzindo-o, muitas vezes, à importação e à adaptação de conceitos europeus.

Dois fatos podem ajudar a ilustrar de que forma a memória colonial é um processo complexo de constituição e de interesses diversos.

Apresento-os.

Em 1988, o Brasil preparava-se para os festejos do centenário da abolição da escravatura. De um lado, o Estado brasileiro propunha uma série de homenagens, tendo seu ponto alto em 13 de maio, dia da assinatura da Lei Áurea. De outro lado, o movimento negro organizava-se no apagamento dessa data e cobrava, em debate público, uma autonomia para firmar sua própria agenda, a qual atendesse aos interesses históricos, éticos e políticos do seu movimento. Uma das cobranças era a transferência da data das celebrações e homenagens: a revogação de quaisquer comemorações no dia 13 de maio e sua substituição oficial pela data de 20 de novembro, morte de Zumbi dos Palmares ${ }^{36}$. O

\footnotetext{
${ }^{35}$ MBEMBE, Achillè. Necropolitica. Revista do PPGAV/EBA/UFRJ, n. 32, p. 126. 2016.

${ }^{36}$ Interessante é registrar os embates na construção dessa memória. Dentre muitas personalidades reunidas na Rua da Praia, no Centro de Porto Alegre, em 1971, a primeira proposta foi apresentada por Oliveira Ferreira da Silveira (1941-2009) após pesquisas em livros de Edison Carneiro (Quilombo dos Palmares) indicando que Zumbi havia sido morto em 20 de novembro. A informação foi também confirmada no livro As guerras dos Palmares, de Ernesto Ennes. A intenção clara daquele grupo era a substituição do dia 13 de maio por uma data representativa para o povo negro. A partir de meados dos anos de 1970, a data começou a ser comemorada também em São Paulo e no Rio de Janeiro. Nos 90 anos da abolição, em 1978, o Movimento Negro Unificado Contra a Discriminação (MNU) aprovou, em assembleia realizada na Bahia, o dia 20 de novembro como o dia de celebrações oficiais a comunidade negra brasileira.
} 
momento foi de polêmicas entre narrativas que se misturavam entre construção e apagamento de memórias na representação do passado. Além disso, houve uma pressão sobre as representatividades simbólicas de quem seriam os "redentores" do processo abolicionista. Para o movimento, "redentores" seriam homens e mulheres negros que participaram, de algum modo, do combate a favor da liberdade do seus. Dessa forma, o mês de novembro passou a ser uma construção de memória do próprio movimento negro, que buscou colocar Zumbi como fonte da população afro-brasileira, em detrimento das propostas do Estado.

O outro fato mencionado trata-se do evento ocorrido nos 131 anos da abolição escravocrata, em 2019. Representantes do Estado brasileiro, em sua maioria parlamentares, homens, brancos - guardiões da memória colonial a partir de um viés que valoriza o colonialismo como um dos grandes pilares da civilização brasileira realizaram homenagens no dia 14 de maio no Senado Federal. Para isso, exaltaram a princesa Isabel dando-lhe um papel de destaque na comemoração, quando reassumiu a imagem de redentora, feminista e a libertadora do povo negro. Representantes do movimento negro - diga-se de passagem, impedidos de adentrar ao evento realizado a portas fechadas no plenário Ulysses Guimarães -, buscavam, por sua vez, protestar sobre a representatividade do evento e o lugar dado a Isabel, já que, havia alguns anos, o movimento vinha trabalhando na desconstrução dos simbolismos na imagem da princesa. O movimento negro, cada vez mais, busca firmar personagens e fatos negros como responsáveis pelo processo que eclodiu na assinatura da Lei Áurea em maio de 1888. 


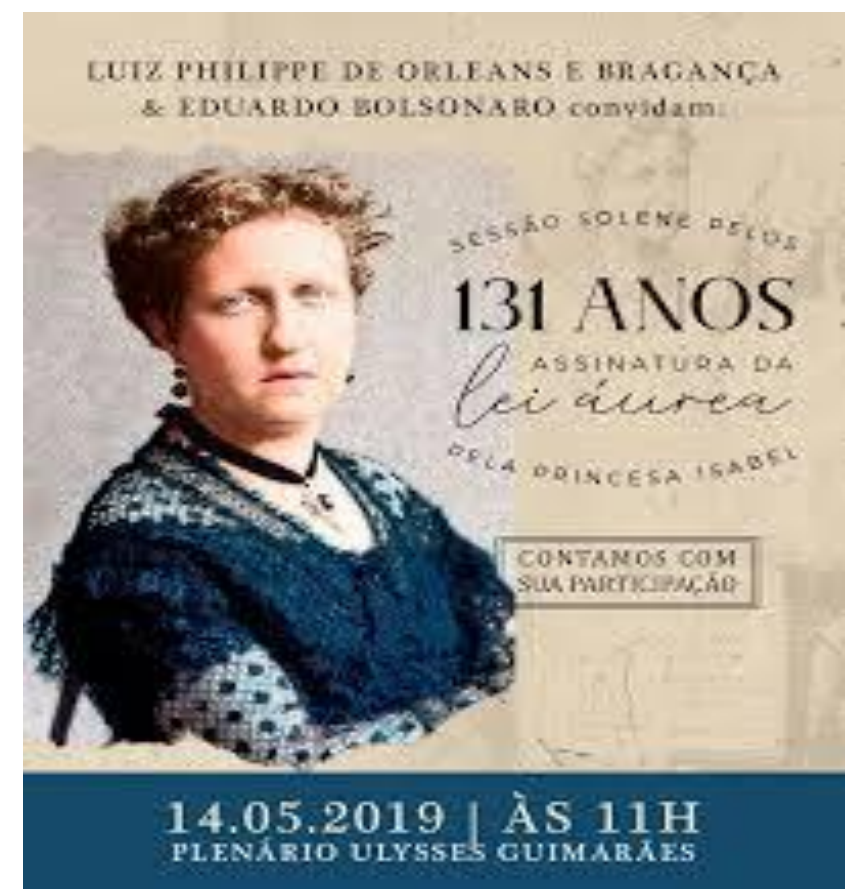

Convite para sessão solene pelos 131 anos da assinatura da Lei Áurea.

Fonte: https://bit.ly/31iqzVj. Acesso em 2 de agosto de 2019

Nesse sentido, pensar em memória colonial de forma metodológica é, antes de tudo, descolonizar os referenciais. É fundamental observarmos que todo o processo de construção do negro deu-se por um viés que valorizou a voz dos vencedores: homens, brancos, descendentes de europeus. O lugar ocupado pelo negro é, muitas vezes, o da falta de agência humana, ou seja, aquele em que o africano ou o negro da diáspora é descartado como ator ou protagonista em seu próprio mundo; "é a destruição de sua personalidade material e espiritual" 37 .

Finalmente, a memória social é um campo de interações, representações e simbolismos que visam a atender a interesses de atores diversos. Em analogia, a memória colonial pode tornar-se fonte de investigação e problematização, na medida em que pode ventilar as construções, as representações e interesses de diferentes grupos. É importante jogar luz sobre questões que envolvam como e de que forma esses diferentes grupos, dentro de um processo colonialista, racista e culturalmente derramado, na taça da branquitude, buscam construir suas lembranças coloniais e traumáticas ainda hoje. A

\footnotetext{
37 ASSANTE, Molefi. Afrocentricidade: notas sobre uma posição disciplinar. In NASCIMENTO, Elisa. Afrocentricidade. Uma abordagem epistemológica inovadora. Selo negro edições. Rio de Janeiro: Ed: Selo Negro edições,p.93, 2009.
} 
quais interesses busca-se atender a partir desses pressupostos nas análises simbólicas, iconográficas ou históricas do período é uma questão.

A memória colonial é uma memória traumática, esculpida na bestialidade e customizada na desumanização. Ela é mantida a partir da assimilação cultural e social cujo interesse é desumanizar qualquer traço identitário étnico-cultural. É aí, justamente, que a memória colonial deve ser questionada: é na decolonização teórica e metodológica, é na problematização das estratégias usadas por colonizados e é na força alienatória usada por colonizadores no processo de violação e de abnegação de direitos culturais.

Se, por um lado, um grupo busca oficializar as lembranças de acordo com os seus interesses desse período, pelo outro, outro grupo busca reconstituir-se em meio aos silêncios e apagamentos forçados; relembrar as suas memórias traumáticas por um viés que ilumine práticas de reexistência. Tal reexistência pode objetivar alcançar não apenas direitos humanos e indenizações, mas também políticas públicas, revisionismos históricos e o estabelecimento de epistemologias que atendam aos interesses dos silenciados.

\section{MAAFA, HOLOCAUSTO, MEMÓRIA E DIREITOS}

O século XX foi catastrófico para os europeus no que pende às violências sofridas por diferentes povos em diversos países. As duas grandes Guerras Mundiais; a queda dos impérios coloniais que desapareceram em 1914; o aumento da brutalização e da desumanização traumatizaram toda Europa. Esse século foi ainda abalado por sucessivas crises econômicas capitalistas, provocando "guerras civis" em diferentes regiões de toda a Europa e a consequentes fugas e emigrações forçadas.

O sistema democrático europeu foi salvo após a Segunda Guerra Mundial graças aos acordos que visavam a atender aos interesses do sistema capitalista e comunista, empenhados em derrotar o sistema nazo-fascista liderado por Adolf Hitler. O colapso das civilizações, as mortes seguidas por desumanização de corpos traumatizaram diferentes sociedades europeias e culminaram na criação da ONU, projeto estabelecido em parceria com os aliados norte-americanos.

Ali, os Direitos Universais do Homem foram definidos após os horrores visto pelo mundo europeu e seus aliados. A experiência traumática proporcionou a criação de novas palavras para categorizar as barbáries e definir as circunstâncias: os "sem Estado" tornaram-se "apátridas" e os assassinatos ou destruições em massa de quaisquer grupos sociais tornaram-se "genocídios". Essas palavras objetivavam criminalizar os eventos traumáticos experimentados pelo povo europeu, assim como evitar eventos similares no 
futuro, embora os horrores ocorridos nas sucessivas batalhas do século XX não tenham sido as primeiras experiências brutais e vergonhosas vividas pela humanidade.

É preciso contextualizar que, naquele momento, as grandes potências europeias assistiam perplexas à queda de seus impérios, à guerra, à fome, à tortura e à deportação forçada de seus povos. Por outro lado, em um passado não muito distante, foram esses mesmos impérios europeus que participaram da dizimação de povos e sociedades africanas e indianas e também da destruição das culturas autóctones das Américas, esfoliadas em nome da colonização do "Novo Mundo". Mais controverso é o fato de a independência de diversas colônias do continente africano ocorrem somente no período das guerras europeias. Kwame Ture ${ }^{38}$ argumenta que, enquanto Hitler enfraquecia a Europa imperialista a partir da Itália, da França e da Bélgica, o continente africano libertava-se dos efeitos da Conferência de Berlim, que repartiu o continente entre as potências europeias ${ }^{39}$.

Dito isso, é importante frisarmos todas as problemáticas e riscos colocados no confronto entre direitos humanos e memórias traumáticas de um grupo em relação a outro. As disputas em torno das memórias e direitos humanos do holocausto em relação às lembranças e direitos da memória colonial é um bom exemplo, na medida em que ambas têm o racismo como seu projeto ideológico - ainda que o sujeito negro seja sempre marcado pela cor da sua pele. É necessário particularizar essas memórias traumáticas de determinados grupos étnicos e raciais. Andreas Huyssen ${ }^{40}$ defende a tarefa em reconhecer uma dimensão universal na opressão e no sofrimento entre as memórias traumáticas. É fundamental que uma lembrança não subjugue outra. Franz Fanon ${ }^{41}$ define como utópico querer saber como um comportamento desumano diferencia-se de outro comportamento desumano.

As humilhações, práticas de sevícias e assassinatos praticados por sicários traficantes europeus do Atlântico, invasores coloniais do século XVI ao XX - contra os negros da África ou os Indianos levaram o pensador Aimé Césaire a questionar, em seu indigesto e realista ensaio discurso sobre o colonialismo, sobre os riscos da igualação

\footnotetext{
${ }^{38}$ TURE, Kwame. (1996) Kwame Ture vs Molefi Asante Africa and the Future Debate Pan Africanism vs Afrocentrism Disponível em : https://www.youtube.com/watch?v=BeWcBU1m5ug\&t=3050s. Acesso em 16 de agosto de 2019.

${ }^{39}$ Fonte: https://www.youtube.com/watch?v=BeWcBU1m5ug. Acesso em: 13 ago. 2019.

${ }^{40}$ HUYSSEN, Andreas. Culturas do passado-prente. Modernismos, artes visuais, políticas da memória. Rio de Janeiro: Ed. Contraponto, 2014.

${ }^{41}$ FANON, Franz. Peles negras; máscaras brancas. Salvador: EDUFBA, 2008.
} 
entre memórias traumáticas ou de qualquer comparação entre racismos. Césaire postula que:

\begin{abstract}
Valeria a pena estudar, com detalhe clínico, as formas de atuar de Hitler e do Hitlerismo, e revelar ao muito distinto, muito humanista, muito cristão burguês do século XX, que ele carrega consigo um Hitler que ele ignora, que Hitler o habita, que Hitler é o seu demônio; que se ele o vitupera, é por falta de lógica, e que, no fundo, o que ele não perdoa a Hitler não é o crime em si, o crime contra homem, não é a humilhação em si, senão o crime contra o homem branco; a humilhação do homem branco, e o fato de ter aplicado à Europa procedimentos colonialistas que até agora só se infligiam aos árabes da Argélia, aos Coolies da Índia e aos Negros da África (grifos nossos) ${ }^{42}$.
\end{abstract}

É preciso frisar que a criação da ONU ocorreu em 1945, após a Segunda Guerra Mundial. A Declaração Universal dos Direitos do Homem, de 1948, buscou ser um documento marco no reconhecimento do direito à dignidade humana. $\mathrm{O}$ conceito de genocídio, postulado pelo jurista Raphael Lemkin, foi criado em virtude do genocídio armênio, em 1943, entretanto, somente foi acolhido em Assembleia da ONU em 1946. Essa conceituação buscou evitar quaisquer dimensões particulares do holocausto armênio ou judaico, assim como os outros crimes praticados no passado colonial; contundo, houve uma apropriação da memória traumática do holocausto nesse crime, em virtude das diversas condenações em tribunais no pós-guerra.

Nos debates desse período sobre direitos humanos e memória colonial, ao contrário, buscou-se evitar, por exemplo, tribunais, indenizações financeiras ou condenações das potências europeias sobre a esfoliação, colonização e destruição da cultura africana. $\mathrm{O}$ holocausto e o genocídio são termos que, ainda hoje, buscam definir todo o sofrimento do povo judaico ${ }^{43}$. Em contrapartida, o continente africano continua cobrando a devolução de parte de seu patrimônio cultural saqueado por franceses, ingleses e belgas ${ }^{44}$.

Os conceitos de holocausto e genocídio podem ser-nos indicativos dos usos pelos quais memórias traumáticas podem ser debeladas. Ainda que o objetivo deste ensaio não

\footnotetext{
${ }^{42}$ CESAIRE, Aimé; MOORE, Carlos. Le discours sur la négritude. Belo Horizonte: Ed Nandayala Livros e Serviços, p.29, 2010.

${ }^{43} \mathrm{O}$ uso do termo "holocausto" para questões coloniais referentes à escravidão nas Américas, segundo Huyssen (2015), é polêmico e até mesmo inaceitável em alguns círculos acadêmicos alemães.

${ }^{44}$ Fonte: https://www.otempo.com.br/mundo/para-conter-chineses-europa-aceita-devolver-arte-que-tirouda-africa-1.2084091. Acesso em: 5 ago. 2019.
} 
seja comparar traumas humanitários no campo da memória, talvez valesse a pena pontuarmos algumas questões.

Um dos primeiros pensadores brasileiros a assimilar o genocídio judaico ao genocídio da população afro-brasileira foi o intelectual Abdias Nascimento ${ }^{45}$. Em $O$ genocídio do negro brasileiro, Abdias aponta que nosso genocídio ocorreu de forma sistemática desde o período colonial. Além disso, ele denuncia personagens e instituições que, em suas narrativas coloniais, incentivaram o crime do genocídio: a Igreja Católica ou outras denominações cristãs; e os pensadores e intelectuais que, segundo o autor, ainda recorriam a uma visão racista, tais quais Pierre Verger, Gregório de Matos e o padre Antonio Vieira. Abdias busca, de forma pontual, localizar onde nosso genocídio ocorre de forma simbólica, cultural, religiosa, discursiva e de corpos negros por um racismo mascarado.

Nesse sentido, direitos humanos e memória devem, dentro de suas proporções históricas, guardar suas particularidades. É problemático, a partir de uma visão afrocêntrica, recorrer a conceitos como "holocausto" ou "genocídio" para definir as mesmas práticas contra o povo negro durante o processo colonial. $\mathrm{O}$ debate é polêmico e pode acabar por generalizar as particularidades de cada evento. Contudo, essa dificuldade pode ser amenizada com ajuda de pensadores como Marimba Ani ${ }^{46}$ e Maulana Karenga. Ambos propõem o uso do termo Maafa a partir de seus processos de descolonização em torno de questões relativas às memórias traumáticas judaicas ou coloniais. Maafa são todas as atrocidades cometidas contra o povo africano por não africanos (europeus ou árabes), em especial no contexto da escravidão e do comércio atlântico até os dias atuais através do imperialismo, do colonialismo contra o povo negro ou da diáspora negra.

Andreas Huyseen ${ }^{47}$ problematiza questões relativas aos limites e os desafios na dinâmica entre direitos humanos e memória traumáticas de grupos diferentes. Esse pensador apresenta uma crítica aos debates contemporâneos sobre discursos de memória e os direitos humanos, na medida em que são narrativas que, disciplinarmente, se mantêm separadas - uma vez que os direitos humanos são abordados por um campo das ciências humanas, e os estudos de memória, por outro campo das ciências sociais. Por esse ângulo,

\footnotetext{
${ }^{45}$ NASCIMENTO. Abdias. O genocídio do negro brasileiro, 2016. São Paulo. Ed. Perspectiva.

${ }^{46}$ MARIMBA, Any. Let the Circle Be Unbroken: The Implications of African Spirituality in the Diaspora, Editora: Red Sea Pr, Africa, 1994

${ }^{47}$ HUYSSEN, Andreas. Culturas do passado-presente. Modernismos, artes visuais, políticas da memória. Rio de Janeiro: Ed. Contraponto, 2014
} 
direitos humanos e memória podem tornar-se tanto uma promessa, na medida em que buscam atentar para os crimes contra humanidades praticados ontem e hoje, quanto um problema, posto que podem buscar universalizar memórias traumáticas subjugando as dores de determinados povos a outros.

Essas questões levam-me a questionar sobre a possibilidade de uma memória global, transnacional, por exemplo. Poderia a antiga noção de memória coletiva ou a memória de determinado grupo social, de Maurice Halbwachs ${ }^{48}$, ser repensada a um nível universal em se tratando de memórias traumáticas?

O que podemos observar é que, pelo menos desde a década de 1990, em virtude da tecnologia e da globalização a nível econômico e social, o status das memórias coletivas vem se tornando cada vez mais desfragmentado. Assim sendo, se pensamos em uma memória cultural - e quando falo em cultura, compreendo a memória de determinado grupo e as suas reivindicações culturais -, como poderíamos pensar em um direito à memória cultural de grupos vulneráveis em diferentes contextos?

Há alguns anos, mais de dezesseis países europeus tornaram tipificado penalmente qualquer espécie de negacionismo relativo ao holocausto. No início dos anos 2000, diversos países propuseram uma detenção de um a quatro anos para todo aquele que negasse o acontecimento da tragédia. O linguista e ativista político Noam Chomsky foi questionado em virtude de suas colocações relativas ao holocausto ${ }^{49}$. Esse fato leva-nos a questionar, por exemplo, sobre a mesma possibilidade de tipificar negações relativas ao passado colonial, às mortes dos negros nos crimes coloniais que reverberam, ainda hoje, em todo silêncio e negação que os cerca. Haveria possibilidades jurídicas para tipificações que neguem a escravidão, a morte de escravizados e a matança descontrolada de negros na atualidade?

São muitos os riscos na comparação entre memórias traumática e direitos humanos. A memória em torno do holocausto judaico estabeleceu-se a partir de um pensamento pós-guerra, contudo, não se faz qualquer menção aos traumas do sistema escravocrata colonial. É necessário reconhecer as particularidades de cada caso, sem retificá-las. É preciso atenuar as lembranças rivais de sofrimento e perseguição. Urge a necessidade de estudos étnico-raciais que tratem de direitos humanos e memória por um

\footnotetext{
${ }^{48}$ HALBWACHS, Maurice. Memória Coletiva, São Paulo: Centauro, 2006.

49 https://expresso.pt/actualidade/israel-nega-entrada-a-noam-chomsky=f583232. Acesso em 16 de agosto de 2019
} 
viés que privilegie epistemologias negras como as propostas por Mbembe $^{50}$ e outros pensadores.

Finalmente, entendo que conceitos utilizados para questões do holocausto judaico podem, sim, ser utilizados em questões traumáticas de outros povos, tais quais os holocaustos e genocídios de negros, índios, armênios, ciganos, imigrantes forçados e outras classes sociais em situação de vulnerabilidade. Contudo, o que proponho é que possamos avançar nessas questões privilegiando estudos e pensadores que busquem desenvolver possibilidades de práxis, é quiçá jurídicas, que contemplem estudos étnicoraciais.

O debate sobre direitos humanos e sistema colonial escravocrata, no caso brasileiro, atua por outro viés. No caso judaico ou armênio, por exemplo, objetivou-se a criação de tribunais e a condenação dos responsáveis ou participantes daquelas atrocidades. O movimento negro, ao contrário, sempre objetivou a cobrança de pautas reivindicativas que privilegiassem políticas públicas. Porque, de fato, o que podemos observar é que a condenação de crimes contra o genocídio e o holocausto do povo judaico jamais impediu os mesmos crimes contra os povos negros ou indígenas ${ }^{51}$.

Há, nesse sentido, a necessidade de analisar os silêncios e apagamentos da cultura afro-brasileira por um viés que valorize esses silêncios como meio de resistências. É necessário escapar de teorias sobre memórias e memórias traumáticas ao abordar o esquecimento ora como algo naturalmente posto no campo da memória social, ou como alguma coisa negativa e vazia de interpretações ao subalternizar epistemologias próprias de cada grupo ao retirar as possibilidades do protagonismo e de representatividade de cada herdeiro de suas próprias memórias sociais, coloniais e traumáticas.

\section{CONSIDERAÇÕES FINAIS}

À guisa de reflexões conclusivas deste artigo, dedico-me a iluminar as formas contemporâneas de interações de como a memória colonial é subjugada a outras memórias traumáticas. Além disso, a memória colonial brasileira, no que concerne ao

\footnotetext{
50 MBEMBE, Achillè. Crítica da razão negra. Editora n. 1 edições, 2018; MBEMBE, Achillè. Necropolitica. Revista do PPGAV/EBA/UFRJ, n. 32, pp. 123-151. 2016

${ }^{51}$ Segundo dados do Atlas da Violência, entre 2002 e 2010, o número de negros assassinados aumentou $29,8 \%$, enquanto o número de assassinatos de brancos caiu $25,5 \%$. Se, em 2002, foram 30 mil negros assassinados no país, em 2010, esse número alcançou a marca de 34.983 negros assassinados. Em 2017, as taxas alcançaram uma média de 49.524 mortes. Em 15 anos, houve um aumento de 33\% de mortes de negros, confirmando a cor da violência. Fonte: https://noticias.uol.com.br/cotidiano/ultimasnoticias/2019/06/05/taxa-de-homicidio-de-negros-aumenta-33-em-10-anos-segundo-o-ipea.htm. Acesso em: 6 ago. 2019.
} 
lugar do negro no imaginário social, é profundamente manipulada por um silêncio que busca apagar as resistências e os fatos heroicos do movimento negro. Busquei, ainda que de forma inicial, demonstrar que as noções de memórias traumáticas (genocídio, memoricídio, holocausto) e direitos humanos é insuficiente para resumir e condenar nossos apagamentos de memória, tendo em vista as violências cotidianas sofridas na contemporaneidade pela população negra.

No mais, proponho a noção de necromemória para abarcar as várias maneiras pelas quais as nossas memórias coloniais (revoltas, quilombos, personalidades, lugares de memória, línguas, intelectuais negros) são silenciadas até a atualidade. São silêncios, manipulações e apagamentos disponibilizados com o objetivo de provocar a destruição de um passado heroico; é um projeto político de silenciamento forçado e manipulado para os fatos e sujeitos negros. Busca-se destruir os fatos, os lugares, os saberes, a religião e as oralidades como formas constantemente renováveis de manipular o hoje a partir das ausências dessas memórias. Sujeitos sem passado não conseguem politizar seus futuros. Nessas topografias, esculpidas na violência colonial permanente, sugiro que a necromemória seja uma tentativa em ventilar as redes, as fronteiras corpóreas entre histórias "oficiais" e extraoficiais, silêncios e lembranças, morte e vida. 


\section{REFERÊNCIAS BIBLIOGRÁFICAS}

ASSANTE, Molefi. Afrocentricidade: notas sobre uma posição disciplinar. In NASCIMENTO, Elisa. Afrocentricidade. Uma abordagem epistemológica inovadora. Selo negro edições. Rio de Janeiro: Ed: Selo Negro edições, 2009.

BUTLER. Judith. Introdução. In Quadros de guerra. Rio de Janeiro: Civilização Brasileira, 2015, pp. 13-55.

BAEZ, Fernando. A história da destruição cultural da América Latina: da conquista à globalização. Rio de Janeiro: Editora Nova Fronteira, 2010.

BENJAMIN, Walter. Sobre o conceito de história. . In: . Obras Escolhidas. Magia e técnica, Arte e politica. Rio de Janeiro: Brasiliense, p. 222-232, 1985.

BIKO, Stephen. Escrevo o que eu quero. São Paulo: Ed. Ática, 1978

CAMILO, Vandelir. Vestígios da memória de Antonio José Nunes Garcia: A trajetória e o esquecimento de um jornalista, professor e literato negro do século XIX (1813-1894) Revista Mosaico, Debates sobre racismo e antirracismo no pensamento social brasileiro. v. 12 n. 19.2020

CAMILO, Vandelir. Homem de cor: as performatividades de um "mulato" frente ao racismo Doutor José Mauricio Nunes Garcia Junior (1808-1884) Revista de Pesquisa Historia Clio. v. 38, n. 2 (2020)

CESAIRE, Aimé; MOORE, Carlos. Le discours sur la négritude. Belo Horizonte: Ed Nandayala Livros e Serviços, 2010.

FANON, Franz. Peles negras; máscaras brancas. Salvador: EDUFBA, 2008.

GARRIDO, Miriam. Escravo, africano, negro e afrodescendente: A representação do negro no contexto pós-abolição e o mercado de materiais didáticos (1997-2012). São Paulo: Ed Alameda, 2017.

GONDAR. Jô. Cinco Proposições sobre Memória Social. Morpheus. № 9, v. 15, p. 1940, 2011.

GONZALEZ, Lélia. Por um feminismo Afro-latino-Americano. In Caderno de Formação do Círculo Palmarino. n. 1. Batalha de ideias. São Paulo. Ed AfroLatinoAmerica, 2011.

HOBSBAWM, Erick. A era da catástrofe. In . A era dos extremos: O breve século XX. São Paulo: Companhia das Letras, 1994, pp. 29-60.

HALBWACHS, Maurice. Memória Coletiva, São Paulo: Centauro, 2006.

HUYSSEN, Andreas. Culturas do passado-presente. Modernismos, artes visuais, políticas da memória. Rio de Janeiro: Ed. Contraponto, 2014

LATOUR, Bruno. Jamais fomos modernos: ensaio de antropologia simétrica. Tradução de carlos Irineu da Costa. 2. Ed. Rio de janeiro: Ed. 34, 2009

LEMKIN, Raphael. Axis Rule in Occupied Europe: Laws of Occupation - Analysis of Government - Proposals for Redress, Washington, D.C.: Carnegie Endowment for International Peace p. $79 \quad-\quad 95.1944$ Disponível em: 
http://www.preventgenocide.org/lemkin/AxisRule1944-1.htm. Acesso em 16 de agosto de 2019.

MBEMBE, Achillè. Crítica da razão negra. Editora n. 1 edições, 2018.

MBEMBE, Achillè. Necropolitica. Revista do PPGAV/EBA/UFRJ, n. 32, pp. 123-151. 2016

MBEMBE, Achillè. Necropolitica. Biopoder, soberania, estado de exceção. Editora: n. 1 ediçoes. São Paulo, 2018

MARIMBA, Any. Let the Circle Be Unbroken: The Implications of African Spirituality in the Diaspora, Editora: Red Sea Pr, Africa, 1994

MORIN, Edgard. Introdução ao pensamento complexo. Porto Alegre. Ed. Sulina, 2005

NASCIMENTO. Abdias. O genocídio do negro brasileiro, 2016. São Paulo. Ed. Perspectiva.

OLICK, Jeffrei.; VINITZKY-SEROUSSI, Vered.; LEVY, Daniel. Introduction. In 3-62. . The collective memory reader. Nova York: Oxford University Press, 2011, pp.

KARENGA, Maulana. Introduction to Black Studies. Mali, Ed. Univ of Sankore, 2002

RICOUER, Paul. A memória, a história, o esquecimento. Tradução: Alain François. Campinas: Editora da UNICAMP, 2007.

ROSSI, Paolo. Lembrar e esquecer. In: O passado, a memória, o esquecimento.

São Paulo: EdUNESP, p. 15-38, 2010.

RUMMEL, Rudolph. Death by Government: Genocide and Mass Murder Since 1900, San Diego, CA, Ed. Edição: 5th PRINTING1, 1997

SOUZA, Jessé. A elite do atraso: da escravidão a lava jato. Rio de Janeiro. Ed. Casa da Palavra, 2017

SCHWARCZ, Lilia. O espetáculo das raças: cientistas, instituições e questão racial no Brasil, 1870-1930. São Paulo: Ed. Companhia das Letras, 1993.

TURE, Kwame. Kwame Ture vs Molefi Asante Africa and the Future Debate Pan Africanism vs Afrocentrism Disponível em : https://www.youtube.com/watch?v=BeWcBU1m5ug\&t=3050s. Acesso em 16 de agosto de 2019

VERNANT, Jean. Mito e pensamento entre os gregos. São Paulo. Edusp, 1973

Data de submissão: $25 / 04 / 2021$

Data de aceite: 18/12/2021 